\title{
Comparing the Effects of Tidal Volume, Driving Pressure, and Mechanical Power on Mortality in Trials of Lung-Protective Mechanical Ventilation
}

\author{
Jose Dianti, John Matelski, Manuel Tisminetzky, Allan J Walkey, Laveena Munshi, \\ Lorenzo Del Sorbo, Eddy Fan, Eduardo LV Costa, Carol L Hodgson, Laurent Brochard, \\ and Ewan C Goligher
}

\begin{abstract}
BACKGROUND: The unifying goal of lung-protective ventilation strategies in ARDS is to minimize the strain and stress applied by mechanical ventilation to the lung to reduce ventilator-induced lung injury (VILI). The relative contributions of the magnitude and frequency of mechanical stress and the end-expiratory pressure to the development of VILI is unknown. Consequently, it is uncertain whether the risk of VILI is best quantified in terms of tidal volume $\left(\mathrm{V}_{\mathrm{T}}\right)$, driving pressure $(\Delta \mathrm{P})$, or mechanical power. METHODS: The correlation between differences in $V_{T}, \Delta P$, and mechanical power and the magnitude of mortality benefit in trials of lung-protective ventilation strategies in adult subjects with ARDS was assessed by meta-regression. Modified mechanical power was com-

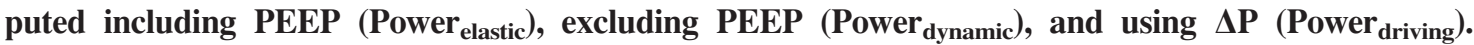
The primary analysis incorporated all included trials. A secondary subgroup analysis was restricted to trials of lower versus higher PEEP strategies. RESULTS: We included 9 trials involving 4,731 subjects in the analysis. Odds ratios for moderation derived from meta-regression showed that variations in $\mathrm{V}_{\mathrm{T}}, \Delta \mathrm{P}$, and Power $_{\text {dynamic }}$ were associated with increased mortality with odds ratios of 1.24 (95\% CI 1.03-1.49), 1.31 (95\% CI 1.03-1.66), and 1.37 (95\% CI 1.05-1.78), respectively. In trials comparing higher versus lower PEEP strategies, Power $_{\text {elastic }}$ was increased in the higher PEEP arm $(24 \pm 1.7$ vs $20 \pm 1.5 \mathrm{~J} / \mathrm{min}$, respectively), whereas the other parameters were not affected on average by a higher PEEP ventilation strategy. CONCLUSIONS: In trials of lungprotective ventilation strategies, $\mathbf{V}_{\mathrm{T}}, \Delta \mathbf{P}$, Power $_{\text {elastic }}$, Power $_{\text {dynamic, }}$ and Power $_{\text {driving }}$ exhibited similar moderation of treatment effect on mortality. In this study, modified mechanical power did not add important information on the risk of death from VILI in comparison to $\mathbf{V}_{T}$ or $\Delta P$. Key words: ARDS; VILI; mechanical ventilation; mechanical power; lung-protective strategies; metaregression. [Respir Care 2021;66(2):221-227. (C) 2021 Daedalus Enterprises]
\end{abstract}

\section{Introduction}

The unifying goal of lung-protective ventilation strategies in ARDS is to minimize the strain and stress applied by mechanical ventilation to the injured lung,

Drs Dianti, Tisminetzky, Munshi, Del Sorbo, Fan, Brochard, and Goligher are affiliated with the Interdepartmenal Division of Critical Care Medicine, University of Toronto, Toronto, Ontario, Canada. Dr Matelski is affiliated with the Biostatistics Research Unit, University Health Network, Toronto, Ontario, Canada. Dr Walkey is affiliated with the Pulmonary Center, Boston University School of Medicine, Boston, Massachusetts. Dr Costa is affiliated with the Research and Education Institute, Hospital Sírio-Libanês, São Paulo, Brazil. Dr Hodgson is affiliated with the Australian and New thereby reducing ventilator-induced lung injury (VILI). ${ }^{1}$ Compelling evidence gathered in the last 20 years has shown that mechanical ventilation with low tidal volume $\left(\mathrm{V}_{\mathrm{T}}\right)$ improves survival of patients with ARDS., ${ }^{2,3}$ Recently, driving pressure $\left(\Delta \mathrm{P}\right.$, normalizes $\mathrm{V}_{\mathrm{T}}$ for compliance, a surrogate of the size of the "baby lung") has

\footnotetext{
Zealand Intensive Care-Research Centre, Monash University, Melbourne, Australia. Dr Brochard is affiliated with the Li Ka Shing Knowledge Institute, Keenan Research Centre, St Michael's Hospital, Toronto, Ontario, Canada. Drs Dianti, Tizminetzky, Munshi, Del Sorbo, Fan, and Goligher are affiliated with the Department of Medicine, Division of Respirology, University Health Network, Toronto, Ontario, Canada.
} 
been shown to be a better predictor of mortality than $\mathrm{V}_{\mathrm{T}}{ }^{4}$ The exact mechanism through which these parameters exert injury on the lung, however, is not clear. ${ }^{5}$ Although it is widely accepted that stress and strain resulting from tidal volume and applied end-expiratory pressure play a key role in the development of VILI, additional components of the mechanical breath (ie, flow and breathing frequency) also appear to contribute to tissue damage. ${ }^{6-8}$

Both $\mathrm{V}_{\mathrm{T}}$ and $\Delta \mathrm{P}$ neglect the impact of flow and breathing frequency on the development of VILI. Mechanical power has been suggested as a summary variable that incorporates all of these parameters into a single, overarching entity. Mechanical power represents the energy applied to the respiratory system to achieve a change from resting lung volume over 1 min. $^{9}$ In other words, it characterizes the relationship between the sum of pressures applied to the respiratory system and the respective changes in lung volume they generate, accounting for the potential influences of flow and breathing frequency as well as $\mathrm{V}_{\mathrm{T}}$ and $\Delta \mathrm{P}$ on VILI. The association between mechanical power and VILI is not new, and it has been demonstrated in animal experiments. ${ }^{10}$ Recently, retrospective observational studies in humans have also linked mechanical power to mortality in subjects with and without ARDS. ${ }^{11-13}$ However, mechanical power also carries a number of limitations, such as its lack of adjustment to the actual functional lung size and the controversial relationship between PEEP, power, and the risk of VILI. ${ }^{14}$ It is therefore uncertain whether the risk of VILI is best quantified in terms of $\mathrm{V}_{\mathrm{T}}, \Delta \mathrm{P}$ or, mechanical power. ${ }^{15}$

We sought to explore this question by quantifying the extent to which the effect of lung-protective ventilation on mortality can be explained by its effect on each parameter in a meta-regression of clinical trials of lung-protective ventilation strategies in ARDS.

\section{Methods}

\section{Search Strategy and Inclusion Criteria}

We consulted a recent systematic review on the use of mechanical ventilation in subjects with $\operatorname{ARDS}^{16}$ and performed a comprehensive search of MEDLINE and PubMed.

\footnotetext{
Dr Goligher has disclosed relationships with Getinge and Timpel. Dr Fan has disclosed relationships with ALung Technologies and MC3 Cardiopulmonary. Dr Brochard has disclosed relationships with Medtronic|Covidien, Air Liquide, Philips, Sentec, General Electric, and Fisher \& Paykel. The other authors have disclosed no conflicts of interest.

Correspondence: Ewan C Goligher MD PhD, Toronto General Hospital, 585 University Ave, 11-PMB Room 192, Toronto ON M5G 2N2, Canada.E-mail: ewan.goligher@uhn.ca.
}

DOI: $10.4187 /$ respcare.07876

\section{QUICK LOOK}

\section{Current knowledge}

Tidal volume $\left(\mathrm{V}_{\mathrm{T}}\right)$ and driving pressure $(\Delta \mathrm{P})$ play a key role in the development of ventilator-induced lung injury (VILI), yet additional components of the mechanical breath, such as breathing frequency, may also contribute to tissue damage. Both $\mathrm{V}_{\mathrm{T}}$ and $\Delta \mathrm{P}$ neglect the effect of breathing frequency on the development of VILI. Mechanical power represents the energy applied to the respiratory system to achieve a change from resting lung volume, accounting for breathing frequency and flow as well as $\Delta \mathrm{P}$ and $\mathrm{V}_{\mathrm{T}}$.

\section{What this paper contributes to our knowledge}

In a meta-regression of trials evaluating lung-protective ventilation strategies in subjects with ARDS, a modified version of mechanical power did not provide additional information about the risk of death from VILI in comparison to $\mathrm{V}_{\mathrm{T}}$ or $\Delta \mathrm{P}$.

The search combined Medical Subject Headings and specific key words to identify trials that evaluated different lung-protective ventilation strategies (eg, lower vs higher $\mathrm{V}_{\mathrm{T}}$ ventilation, lower vs higher PEEP ventilation, and lung recruitment maneuvers) in adult subjects with ARDS, that reported mortality as primary end point, and provided information on the variables required to compute mechanical power on day 1 after randomization. Trials of prone positioning, neuromuscular blockade, extracorporeal life support, and nonconventional modes of ventilation such as high-frequency oscillatory ventilation were excluded because we deemed it unlikely that the mechanism of benefit in these trials could be quantified in terms of $\mathrm{V}_{\mathrm{T}}, \Delta \mathrm{P}$, or mechanical power. This study was performed at the Interdepartmental Division of Critical Care Medicine, University of Toronto.

\section{Data Abstraction}

Two reviewers (JD, MT) independently performed the data abstraction process using a specific data-recording form. Disagreements were resolved by consulting with a third reviewer (ECG). $\mathrm{V}_{\mathrm{T}}, \Delta \mathrm{P}$, and Power on day 1 in both treatment and control arms were recorded.

\section{Mechanical Power Computation}

Considering that the effect of flow in the generation of VILI is unclear because most of the energy generated 


\section{Predicting Mortality in Lung-Protective Ventilation}

by the resistive component of the respiratory system dissipates throughout the proximal airway, we excluded airway resistance from the formula proposed by Gattinoni et $\mathrm{al}^{9}$ to compute a modified mechanical power $\left(\right.$ Power $_{\text {elastic }}$ ) based purely on elastic characteristics of the respiratory system:

$$
\begin{aligned}
& \text { Power }_{\text {elastic }}=0.098 \times f \times \\
&\left(\Delta \mathrm{V}^{2} \times\left[\frac{1}{2} \times \mathrm{ELrs}\right]+\Delta \mathrm{V} \times \mathrm{PEEP}\right)
\end{aligned}
$$

where $f$ is breathing frequency and ELrs is the elastance of the respiratory system. To test the hypothesis that static strain (ie, PEEP-derived strain) has less of an influence in the development of VILI, we also computed modified dynamic mechanical power ( Power $_{\text {dynamic }}$ ) by considering $\mathrm{PEEP}=0 \mathrm{~cm} \mathrm{H}_{2} \mathrm{O}$ in this equation:

$$
\text { Power }_{\text {dynamic }}=0.098 \times f \times\left(\Delta \mathrm{V}^{2} \times\left[\frac{1}{2} \times \mathrm{ELrs}\right]\right)
$$

Finally, driving power (Power driving $_{\text {) }}$ was calculated with the formula proposed by Marini and Jaber ${ }^{5}$ :

$$
\text { Power }_{\text {driving }}=\frac{\Delta \mathrm{P} \times f \times \mathrm{V}_{\mathrm{T}}}{10 \times \mathrm{C}_{\mathrm{RS}}}
$$

where $C_{R S}$ is the compliance of the respiratory system and 10 represents a predicted population averaged normal respiratory-system compliance $\left(0.1 \mathrm{~L} / \mathrm{cm} \mathrm{H}_{2} \mathrm{O}\right)$ suggested by Marini and Jaber ${ }^{5}$ to adjust for the observed "baby lung." Of note, individual patient respiratory-system compliance would be modified by age, gender, height and other conditions.

\section{Statistical Analysis}

The effect size of these 5 potential moderators $\left(\mathrm{V}_{\mathrm{T}}\right.$, $\Delta \mathrm{P}$, Power $_{\text {elastic }}$, Power $_{\text {dynamic }}$, and Power $_{\text {driving }}$ ) on the magnitude of the treatment effect in each trial (odds ratio for mortality at $28 \mathrm{~d}$ or in the ICU, whichever is the primary outcome in the individual trial) was assessed by meta-regression of the trials identified in the systematic review. The primary analysis incorporated all included trials. Because PEEP could have a different effect on the development of VILI depending on how it modifies these parameters, a secondary subgroup analysis was restricted to trials of lower versus higher PEEP strategies. Finally, we also examined the association between each variable and the risk of death across trials using generalized linear mixed-effects regression (GLMER). All statistical analyses were conducted in R 3.4.4.

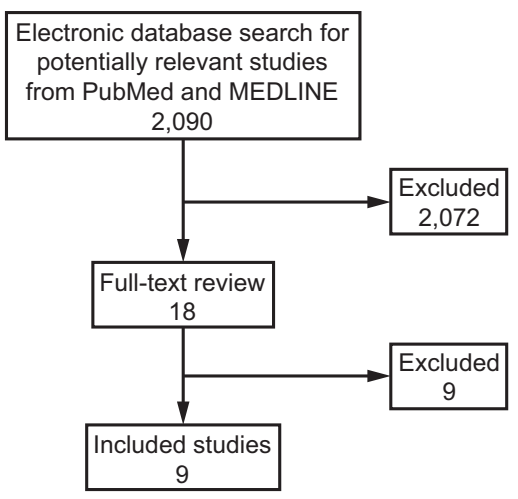

Fig. 1. Flow chart.

\section{Results}

The literature search generated 2,090 titles, of which 2,072 were excluded; 18 studies were selected for fulltext review. Of these, 9 met exclusion criteria or had missing data, ${ }^{17-25}$ for a total of 9 trials ${ }^{2,3,26-32}$ involving 4,731 subjects for analysis (Fig. 1). Characteristics of the selected trials are described in Table 1 . We observed moderate heterogeneity between the included studies $\left(\mathrm{I}^{2}=55.8 \%\right)$.

In these 9 trials, the effect of the intervention on each moderator varied widely between trials (Fig. 2). Odds ratios for moderation derived from meta-regression showed that variations in $\mathrm{V}_{\mathrm{T}}, \Delta \mathrm{P}$, and Power $_{\text {dynamic }}$ from the trial interventions were associated with increased mortality (Table 2). Of these, Power $_{\text {dynamic }}$ exhibited the highest odds ratio, but $95 \%$ CIs overlapped substantially for all moderators. The association between treatment effect size and Power $_{\text {elastic }}$ or Power driving was the weakest. Similar results were observed in the GLMER analysis, although the effect of Power driving showed narrower confidence intervals (Table 2).

In the subset of trials comparing higher versus lower PEEP strategies, Power $_{\text {elastic }}$ was increased in the higher PEEP arm. On average, the reduction in $\triangle \mathrm{P}$ and modified mechanical power parameters obtained from lowering $V_{T}$ was much larger than that obtained by increasing PEEP (Table 3).

\section{Discussion}

In trials of lung-protective ventilation strategies, several parameters of risk for VILI $\left(\mathrm{V}_{\mathrm{T}}, \Delta \mathrm{P}\right.$, Power $_{\text {elastic }}$, Power $_{\text {dynamic }}$, Power driving $_{\text {}}$ ) exhibited similar moderation of treatment effect on mortality. Our findings suggest that a modified mechanical power does not add important information about the risk of death from VILI in comparison to other commonly used static parameters such as $\mathrm{V}_{\mathrm{T}}$ or $\Delta \mathrm{P}$. Unlike the other parameters, Power $_{\text {elastic }}$ did 
Table 1. Characteristics of Included Trials

\begin{tabular}{|c|c|c|c|c|c|c|}
\hline Study & $\begin{array}{c}\text { Centers, } \\
\text { no. }\end{array}$ & Intervention & Control & $\begin{array}{l}\text { Subjects, } \\
n\end{array}$ & $\begin{array}{l}\text { Primary } \\
\text { Outcome }\end{array}$ & Primary Finding \\
\hline Amato et $\mathrm{al}^{2}$ & 2 & $\begin{array}{l}\mathrm{V}_{\mathrm{T}} 6 \mathrm{~mL} / \mathrm{kg} \mathrm{PBW}+\mathrm{LRM}+ \\
\text { PEEP per best } \mathrm{C}_{\mathrm{RS}}\end{array}$ & $\mathrm{V}_{\mathrm{T}} 12 \mathrm{~mL} / \mathrm{kg}$ PBW & 53 & 28-d mortality & $\begin{array}{l}\text { Decreased mortality in } \\
\text { intervention arm }\end{array}$ \\
\hline Brower et $\mathrm{al}^{3}$ & 10 & $\mathrm{~V}_{\mathrm{T}} 6 \mathrm{~mL} / \mathrm{kg} \mathrm{PBW}$ & $\mathrm{V}_{\mathrm{T}} 12 \mathrm{~mL} / \mathrm{kg}$ PBW & 861 & $\begin{array}{c}\text { Death before } \\
\text { discharge }\end{array}$ & $\begin{array}{l}\text { Decreased mortality in } \\
\text { intervention arm }\end{array}$ \\
\hline Brower et $\mathrm{al}^{26}$ & 23 & High PEEP/ $/ \mathrm{F}_{\mathrm{IO}_{2}}$ table & Low PEEP/F $\mathrm{F}_{\mathrm{IO}_{2}}$ table & 549 & $\begin{array}{c}\text { Death before } \\
\text { discharge }\end{array}$ & $\begin{array}{l}\text { No difference in primary } \\
\text { outcome between arms }\end{array}$ \\
\hline Villar et $\mathrm{al}^{27}$ & 8 & $\begin{array}{l}\mathrm{V}_{\mathrm{T}} 5-8 \mathrm{~mL} / \mathrm{kg} \mathrm{PBW}+\mathrm{PEEP} \\
\text { per best } \mathrm{C}_{\mathrm{RS}}\end{array}$ & $\mathrm{V}_{\mathrm{T}}$ 9-11 mL/kg PBW & 95 & ICU mortality & $\begin{array}{l}\text { Decreased mortality in } \\
\text { intervention arm }\end{array}$ \\
\hline Meade et $\mathrm{al}^{28}$ & 30 & $\begin{array}{c}\mathrm{V}_{\mathrm{T}} 6 \mathrm{~mL} / \mathrm{kg} \mathrm{PBW}+\mathrm{LRM}+ \\
\text { high } \mathrm{PEEP} / \mathrm{F}_{\mathrm{IO}_{2}} \text { table }\end{array}$ & $\begin{array}{c}\mathrm{V}_{\mathrm{T}} 6 \mathrm{~mL} / \mathrm{kg} \mathrm{PBW}+\text { low } \\
\text { PEEP/ } / \mathrm{F}_{\mathrm{IO}_{2}} \text { table }\end{array}$ & 983 & $\begin{array}{l}\text { Hospital } \\
\text { mortality }\end{array}$ & $\begin{array}{r}\text { No difference in primary } \\
\text { outcome between arms }\end{array}$ \\
\hline Mercat et $\mathrm{al}^{29}$ & 37 & $\begin{array}{l}\mathrm{V}_{\mathrm{T}} 6 \mathrm{~mL} / \mathrm{kg} \mathrm{PBW}+\text { high } \\
\text { PEEP* }\end{array}$ & $\begin{array}{l}\mathrm{V}_{\mathrm{T}} 6 \mathrm{~mL} / \mathrm{kg} \mathrm{PBW}+\text { low } \\
\text { PEEP }\end{array}$ & 767 & 28-d mortality & $\begin{array}{l}\text { No difference in primary } \\
\text { outcome between arms }\end{array}$ \\
\hline Kacmarek et $\mathrm{al}^{30}$ & 20 & $\begin{array}{l}\mathrm{V}_{\mathrm{T}} 6 \mathrm{~mL} / \mathrm{kg} \mathrm{PBW}+\mathrm{LRM}+ \\
\text { PEEP per best } \mathrm{C}_{\mathrm{RS}}\end{array}$ & $\begin{array}{l}\mathrm{V}_{\mathrm{T}} 6 \mathrm{~mL} / \mathrm{kg} \mathrm{PBW}+\text { low } \\
\text { PEEP/ } / \mathrm{F}_{\mathrm{IO}_{2}} \text { table }\end{array}$ & 200 & 60-d mortality & $\begin{array}{l}\text { No difference in primary } \\
\text { outcome between arms }\end{array}$ \\
\hline Cavalcanti et al ${ }^{31}$ & 120 & $\begin{array}{l}\mathrm{V}_{\mathrm{T}} 6 \mathrm{~mL} / \mathrm{kg} \mathrm{PBW}+\mathrm{LRM}+ \\
\text { PEEP per best } \mathrm{C}_{\mathrm{RS}}\end{array}$ & $\begin{array}{l}\mathrm{V}_{\mathrm{T}} 6 \mathrm{~mL} / \mathrm{kg} \mathrm{PBW}+\text { low } \\
\text { PEEP/ } / \mathrm{F}_{\mathrm{IO}_{2}} \text { table }\end{array}$ & 1,010 & 28-d mortality & $\begin{array}{l}\text { Increased mortality in } \\
\text { intervention arm }\end{array}$ \\
\hline Hodgson et $\mathrm{al}^{32}$ & 35 & $\begin{array}{l}\mathrm{V}_{\mathrm{T}} 4-6 \mathrm{~mL} / \mathrm{kg} \text { PBW + daily } \\
\mathrm{LRM}+\text { high PEEP per } \mathrm{S}_{\mathrm{pO}_{2}}\end{array}$ & $\begin{array}{l}\mathrm{V}_{\mathrm{T}} 6 \mathrm{~mL} / \mathrm{kg} \mathrm{PBW}+\text { low } \\
\text { PEEP/ } / \mathrm{F}_{\mathrm{IO}_{2}} \text { table }\end{array}$ & 113 & $\begin{array}{r}\text { Ventilator-free } \\
\text { days at } 28 \mathrm{~d}\end{array}$ & $\begin{array}{l}\text { No difference in mortality } \\
\text { between arms (stopped } \\
\text { early) }\end{array}$ \\
\hline
\end{tabular}

* Plateau pressure $\leq 30 \mathrm{~cm} \mathrm{H}_{2} \mathrm{O}$

$\mathrm{V}_{\mathrm{T}}=$ tidal volume; $\mathrm{PBW}=$ predicted body weigh; $\mathrm{LRM}=$ lung recruitment maneuver; $\mathrm{C}_{\mathrm{RS}}=$ compliance of the respiratory system
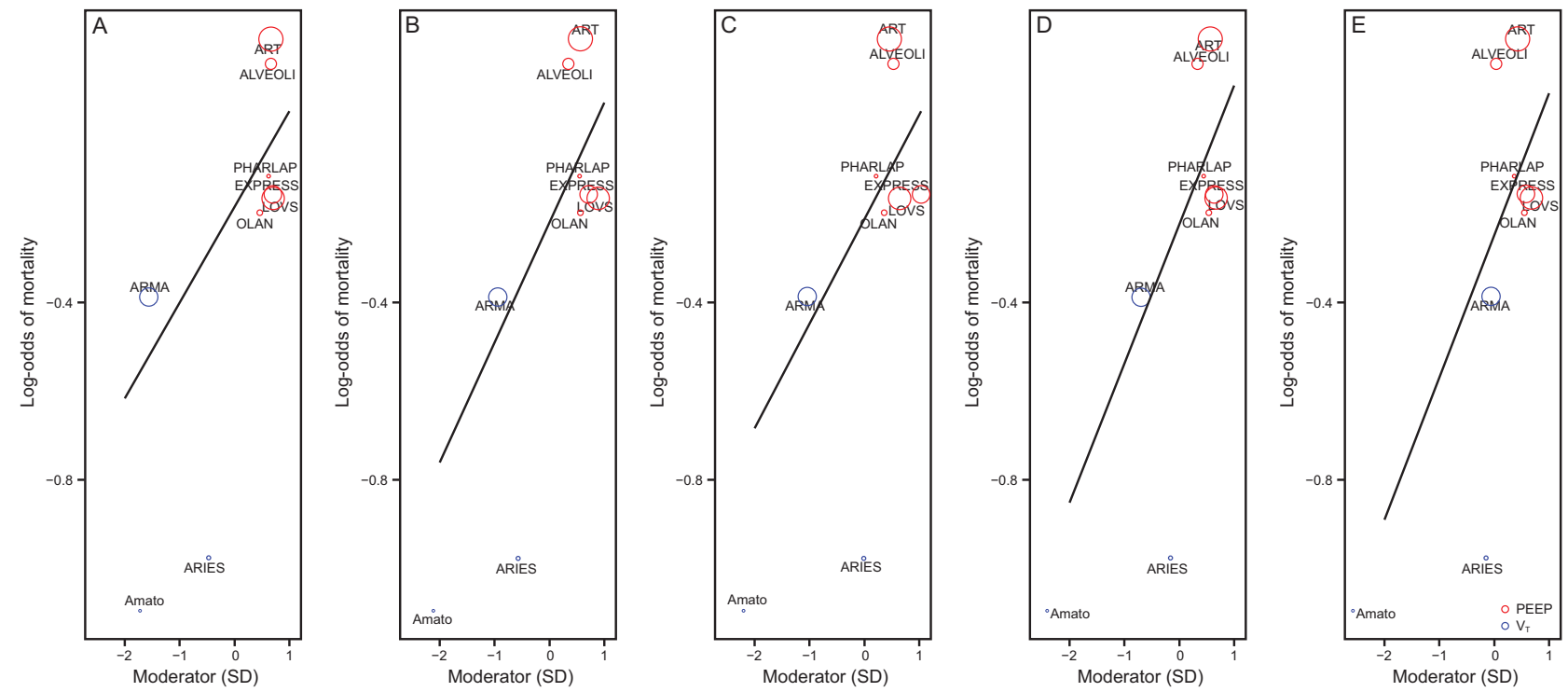

Fig. 2. Moderating effect of tidal volume, driving pressure, mechanical power, dynamic power, and driving power on mortality effect size in trials of lung-protective ventilation strategies.

not reach statistical significance, raising the possibility that including PEEP in the computation of mechanical power degrades, rather than enhances, information about risk of VILI.
The relevance of the inspiratory flow and breathing frequency in the development of VILI has been under scrutiny for many years. Animal studies have reported that higher peak inspiratory flow could worsen gas exchange and lung 
Table 2. Predictors of Treatment Effect and Mortality in Trials of Lung-Protective Mechanical Ventilation

\begin{tabular}{|c|c|c|c|c|}
\hline \multirow[b]{2}{*}{ Parameter } & \multirow{2}{*}{$\begin{array}{c}\text { Distribution Across Trials on } \\
\text { Day } 1 \text { After Randomization, } \\
\text { mean } \pm \text { SD }\end{array}$} & \multicolumn{2}{|l|}{ Meta-Regression } & \multirow{2}{*}{$\begin{array}{c}\text { Generalized Linear } \\
\text { Mixed-Effects Model } \\
\text { Odds Ratio (95\% CI) of } \\
\text { Mortality for a 1-SD } \\
\text { Increase }\end{array}$} \\
\hline & & $\begin{array}{l}\text { Odds Ratio }(95 \% \mathrm{CI}) \text { of Mortality } \\
\text { for a 1-SD Increase in Mean } \\
\text { Difference Between Groups }\end{array}$ & $\begin{array}{c}\text { Meta-regression } \\
\qquad \mathrm{R}^{2}\end{array}$ & \\
\hline $\mathrm{V}_{\mathrm{T}}, \mathrm{mL} / \mathrm{kg} \mathrm{PBW}$ & $6.9 \pm 2$ & $1.24(1.03-1.49)$ & 0.60 & $1.17(1.07-1.29)$ \\
\hline Driving pressure, $\mathrm{cm} \mathrm{H}_{2} \mathrm{O}$ & $15.5 \pm 4.8$ & $1.31(1.03-1.66)$ & 0.48 & $1.24(1.09-1.41)$ \\
\hline Mechanical power, $\mathrm{J} / \mathrm{min}$ & $22.5 \pm 3.6$ & $1.26(.99-1.61)$ & 0.34 & $1.03(0.96-1.11)$ \\
\hline Dynamic power, $\mathrm{J} / \mathrm{min}$ & $8.8 \pm 3.4$ & $1.37(1.05-1.78)$ & 0.60 & $1.24(1.1-1.41)$ \\
\hline Driving power, $\mathrm{cm} \mathrm{H}_{2} \mathrm{O}^{2} / \mathrm{min}$ & $581 \pm 250$ & $1.38(.96-1.96)$ & 0.22 & $1.27(1.08-1.49)$ \\
\hline
\end{tabular}

Table 3. Differences in Parameters Between Intervention and Control Arms

\begin{tabular}{|c|c|c|c|}
\hline & Intervention & Control & Difference \\
\hline \multicolumn{4}{|l|}{$\mathrm{V}_{\mathrm{T}}, \mathrm{mL} / \mathrm{kg}$ PBW } \\
\hline Low versus high $V_{T}$ & $6.1(1.1)$ & $11(0.8)$ & $-4.8(-6.74$ to -2.92$)$ \\
\hline Low versus high PEEP & $5.9(0.5)$ & $6.1(0.3)$ & $-0.16(-0.34$ to 0.01$)$ \\
\hline \multicolumn{4}{|l|}{ Driving pressure, $\mathrm{cm} \mathrm{H}_{2} \mathrm{O}$} \\
\hline Low versus high $V_{T}$ & $15(1.4)$ & $25(2.4)$ & $-10(-14.42$ to -5.77$)$ \\
\hline Low versus high PEEP & $12(1.1)$ & $13(0.9)$ & $-1.5(-2.22$ to -0.83$)$ \\
\hline \multicolumn{4}{|l|}{ Power $_{\text {elastic }}, \mathrm{J} / \mathrm{min}$} \\
\hline Low versus high $V_{T}$ & $19.9(3.9)$ & $26(3.7)$ & $-6(-14.46$ to 2.37$)$ \\
\hline Low versus high PEEP & $24(1.7)$ & $20(1.5)$ & $5(3.47$ to 6.55$)$ \\
\hline \multicolumn{4}{|l|}{ Power $_{\text {dynamic }}, J / m i n$} \\
\hline Low versus high $V_{T}$ & $7.5(2.6)$ & $15.4(2.8)$ & $-7.8(-13.46$ to -2.18$)$ \\
\hline Low versus high PEEP & $7(0.9)$ & $7.9(0.8)$ & $-0.9(-1.37$ to -0.52$)$ \\
\hline \multicolumn{4}{|l|}{ Power $_{\text {driving }}, \mathrm{cm} \mathrm{H}_{2} \mathrm{O} / \mathrm{min}$} \\
\hline Low versus high $V_{T}$ & $544(170)$ & $1,043(265)$ & $-499(-967.05$ to -31.46$)$ \\
\hline Low versus high PEEP & $422(66)$ & $526(79)$ & $-103(-156.58$ to -49.70$)$ \\
\hline
\end{tabular}

compliance when injurious $\mathrm{V}_{\mathrm{T}}$ is delivered. ${ }^{7,8,33}$ This association, however, has not been replicated in studies including humans. Most of the pressure generated by flow is spent to overcome the endotracheal tube's and the proximal airway's dependent resistance. The relevance of inspiratory flow on the development of VILI, a phenomenon that occurs at the alveolar level, is therefore doubtful. ${ }^{15}$ Admittedly, higher flows may entail a more rapid rise in alveolar stress that may be injurious, but in the absence of detailed measurements of airway and alveolar mechanics it is impossible to determine the rate of change in alveolar pressure from the flow. On the other hand, breathing frequency is one of the main components associated with mortality in a retrospective study including $>8,000$ critically ill subjects. ${ }^{11}$ Because mechanical power is meant to reflect the cumulative energy delivered to the respiratory system over a period of time, breathing frequency (and not flow) appears to have a greater physiologic rationale in the development of VILI. Nevertheless, our results do not support the hypothesis that breathing frequency provides additional important information when assessing VILI risk at the bedside.

The lack of meaningful differences in effect moderation by different markers of VILI risk may be attributable to the fact that all of the relevant variation in the parameters resulted from variation in $\mathrm{V}_{\mathrm{T}}$ (because these trials targeted lower $\mathrm{V}_{\mathrm{T}}$ ). Theoretically, the optimal lung-protective strategy should target the parameter that best quantifies the risk of VILI. ${ }^{34}$ However, other mechanisms such as mechanical heterogeneity within the injured lung might also contribute to $\mathrm{VILI}^{35}$ and this may not be captured by any of the aforementioned parameters. 


\section{Predicting Mortality in Lung-Protective Ventilation}

Importantly, we also found that trials of higher versus lower PEEP did not produce meaningful between-group reductions in $\mathrm{V}_{\mathrm{T}}, \Delta \mathrm{P}$, Power $_{\text {elastic }}$, or Power $_{\text {dynamic }}$ (Table 3). If these parameters mediate VILI, failure to modify these parameters might explain in part why these interventions consistently failed to significantly modify mortality. ${ }^{26,28-32}$ Meaningful reductions in $\Delta \mathrm{P}$ and power following increased PEEP would only be expected in subjects who exhibit substantial lung recruitment. The effect of higher versus lower PEEP on $\Delta \mathrm{P}$, mechanical power, and mortality require further study in this specific subgroup.

We observed moderate heterogeneity among the included studies. This enhances the relevance of selecting a metaregression approach to analyze the data, given that a single summary measure might fail to capture the diversity among different subsets of subjects. ${ }^{36}$ This is particularly true when evaluating the effect of mechanical power because its value will be more influenced by changes in $\mathrm{V}_{\mathrm{T}}$ than by changes in PEEP or breathing frequency, ${ }^{9}$ as shown in our secondary analysis. The goal of meta-regression is to determine whether a given parameter (eg, modified mechanical power) can explain the observed statistical heterogeneity.

This study has several limitations. First, the number of trials is small, which limits statistical power to detect moderation of treatment effect. Individual patient data metaanalysis might provide more information. Second, we used physiological and ventilatory data collected at a single time point on the first day of the randomized trial to compute the parameters of interest, and it is unclear how accurately such data reflect overall exposure to the parameters. Moreover, we did not compute mechanical power using the original formula described by Gattinoni et $\mathrm{al}^{9}$ because the information needed to perform this calculation was not available in all of the reviewed studies. Although neglecting the impact of flow on the risk of VILI has a physiological rationale, the derivations presented in this study should only be considered as alternatives.

\section{Conclusions}

In summary, this analysis does not support the hypothesis that mechanical power is a more useful surrogate measure for the risk of death from VILI or for the benefit of lung-protective ventilation strategies in comparison to targeting driving pressure or tidal volume. Individual patient data meta-analysis might provide further information to confirm or refute this conclusion.

\section{REFERENCES}

1. Gattinoni L, Marini JJ, Pesenti A, Quintel M, Mancebo J, Brochard L. The "baby lung" became an adult. Intensive Care Med 2016;42(5): 663-673.
2. Amato MBP, Barbas CSV, Medeiros DM, Magaldi RB, Schettino GP, Lorenzi-Filho G, et al. Effect of a protective-ventilation strategy on mortality in the acute respiratory distress syndrome. N Engl J Med 1998;338(6):347-354.

3. Brower RG, Lanken PN, MacIntyre N, Matthay MA, Morris A, Schoenfeld D, et al. Ventilation with lower tidal volumes as compared with traditional tidal volumes for acute lung injury. New Engl J Med 2000;342(18):1301-1308.

4. Amato MBP, Meade MO, Slutsky AS, Brochard L, Costa ELV, Schoenfeld DA, et al. Driving pressure and survival in the acute respiratory distress syndrome. N Engl J Med 2015;372(8):747-755.

5. Marini JJ, Jaber S. Dynamic predictors of VILI risk: beyond the driving pressure. Intensive Care Med 2016;42(10):1597-1600.

6. Hotchkiss JR, Blanch L, Murias G, Adams AB, Olson DA, Wangensteen OD, et al. Effects of decreased respiratory frequency on ventilator-induced lung injury. Am J Respir Crit Care Med 2000;161(2):463-468.

7. Maeda Y, Fujino Y, Uchiyama A, Matsuura N, Mashimo $T$, Nishimura M. Effects of peak inspiratory flow on development of ventilator-induced lung injury in rabbits. Anesthesiology 2004;101 (3):722-728.

8. Protti A, Maraffi T, Milesi M, Votta E, Santini A, Pugni P, et al. Role of strain rate in the pathogenesis of ventilator-induced lung edema. Crit Care Med 2016;44(9):e838-e845.

9. Gattinoni L, Tonetti T, Cressoni M, Cadringher P, Herrmann P, Moerer O, et al. Ventilator-related causes of lung injury: the mechanical power. Intensive Care Med 2016;42(10):1567-1575.

10. Cressoni M, Gotti M, Chiurazzi C, Massari D, Algieri I, Amini M, et al. Mechanical power and development of ventilator-induced lung injury. Anesthesiology 2016;124(5):1100-1108.

11. Neto AS, Deliberato RO, Johnson AEW, Bos LD, Amorim P, Pereira $\mathrm{SM}$, et al. Mechanical power of ventilation is associated with mortality in critically ill patients: an analysis of patients in two observational cohorts. Intensive Care Med 2018;44(11):1914-1922.

12. Zhang Z, Zheng B, Liu N, Ge H, Hong Y. Mechanical power normalized to predicted body weight as a predictor of mortality in patients with acute respiratory distress syndrome. Intensive Care Med 2019;45 (6):856-864

13. Parhar KKS, Zjadewicz K, Soo A, Sutton A, Zjadewicz M, Doig L, et al. Epidemiology, mechanical power, and 3-year outcomes in acute respiratory distress syndrome patients using standardized screening: an observational cohort study. Ann Am Thorac Soc 2019;16(10): 1263-1272.

14. Tonetti T, Vasques F, Rapetti F, Maiolo G, Collino F, Romitti F, et al. Driving pressure and mechanical power: new targets for VILI prevention. Ann Transl Med 2017;5(14):286.

15. Huhle R, Neto AS, Schultz MJ, de Abreu MG. Is mechanical power the final word on ventilator-induced lung injury? Ann Transl Med 2018;6(19):394

16. Fan E, Sorbo LD, Goligher EC, Hodgson CL, Munshi L, Walkey AJ, et al. An official American Thoracic Society/European Society of Intensive Care Medicine/Society of Critical Care Medicine clinical practice guideline: mechanical ventilation in adult patients with acute respiratory distress syndrome. Am J Respir Crit Care Med 2017;195 (9):1253-1263.

17. Gattinoni L, Tognoni G, Pesenti A, Taccone P, Mascheroni D, Labarta $\mathrm{V}$, et al. Effect of prone positioning on the survival of patients with acute respiratory failure. N Engl J Med 2001;345(8):568-573.

18. Guerin C, Gaillard S, Lemasson S, Ayzac L, Girard R, Beuret P, et al. Effects of systematic prone positioning in hypoxemic acute respiratory failure. JAMA 2004;292(19):2379-2387.

19. Taccone P, Pesenti A, Latini R, Polli F, Vagginelli F, Mietto C, et al. Prone positioning in patients with moderate and severe acute respiratory distress syndrome. JAMA 2009;302(18):1977-1984. 


\section{Predicting Mortality in Lung-Protective Ventilation}

20. Peek GJ, Mugford M, Tiruvoipati R, Wilson A, Allen E, Thalanany $\mathrm{MM}$, et al. Efficacy and economic assessment of conventional ventilatory support versus extracorporeal membrane oxygenation for severe adult respiratory failure (CESAR): a multicentre randomised controlled trial. Lancet 2009;374(9698):1351-1363.

21. Papazian L, Forel J-M, Gacouin A, Penot-Ragon C, Perrin G, Loundou A, et al. Neuromuscular blockers in early acute respiratory distress syndrome. New Engl J Med. 2010;363(12):1107-1116.

22. Guérin C, Reignier J, Richard J-C, Beuret P, Gacouin A, Boulain T, et al. Prone positioning in severe acute respiratory distress syndrome. N Engl J Med 2013;368(23):2159-6218.

23. Combes A, Hajage D, Capellier G, Demoule A, Lavoué S, Guervilly $\mathrm{C}$, et al. Extracorporeal membrane oxygenation for severe acute respiratory distress syndrome. N Engl J Med 2018;378(21):1965-1975.

24. Brochard L, Roudot-Thoraval F, Roupie E, Delclaux C, Chastre J, Fernandez-Mondéjar E, et al. Tidal volume reduction for prevention of ventilator-induced lung injury in acute respiratory distress syndrome. Am J Respir Crit Care Med 1998;158(6):1831-1838.

25. Mancebo J, Fernandez R, Blanch L, Rialp G, Gordo F, Ferrer M, et al. A multicenter trial of prolonged prone ventilation in severe acute respiratory distress syndrome. Am J Resp Crit Care Med 2006;173 (11):1233-1239.

26. Brower RG, Lanken PN, MacIntyre N, Matthay MA, Morris A, Schoenfeld D, et al. Higher versus lower positive end-expiratory pressures in patients with the acute respiratory distress syndrome. New Engl J Med 2004;351(4):327-336.

27. Villar J, Kacmarek RM, Pérez-Méndez L, Aguirre-Jaime A. A high positive end-expiratory pressure, low tidal volume ventilatory strategy improves outcome in persistent acute respiratory distress syndrome: a randomized, controlled trial. Crit Care Med 2006;34(5):1311-1318.
28. Meade MO, Cook DJ, Guyatt GH, Slutsky AS, Arabi YM, Cooper DJ, et al. Ventilation strategy using low tidal volumes, recruitment maneuvers, and high positive end-expiratory pressure for acute lung injury and acute respiratory distress syndrome. JAMA 2008; 299(6):637-645.

29. Mercat A, Richard J-C, Vielle B, Jaber S, Osman D, Diehl J-L, et al. Positive end-expiratory pressure setting in adults with acute lung injury and acute respiratory distress syndrome. JAMA 2008;299(6): 646-655.

30. Kacmarek RM, Villar J, Sulemanji D, Montiel R, Ferrando C, Blanco $\mathrm{J}$, et al. Open lung approach for the acute respiratory distress syndrome. Crit Care Med 2016;44(1):32-42.

31. Cavalcanti AB, Suzumura ÉA, Laranjeira LN, Paisani D de M, Damiani LP, Guimarães HP, et al. Effect of lung recruitment and titrated positive end-expiratory pressure (peep) vs low peep on mortality in patients with acute respiratory distress syndrome: a randomized clinical trial. JAMA 2017;318(14):1335-1345.

32. Hodgson CL, Cooper DJ, Arabi Y, King V, Bersten A, Bihari S, et al. Maximal recruitment open lung ventilation in acute respiratory distress syndrome (PHARLAP): a phase ii, multicenter, randomized, controlled trial. Am J Respir Crit Care Med 2019;200(11):1363-1372.

33. Fujita Y, Fujino Y, Uchiyama A, Mashimo T, Nishimura M. High peak inspiratory flow can aggravate ventilator-induced lung injury in rabbits. Medical Sci Monit 2007;13(4):BR95-BR100.

34. Nieman GF, Satalin J, Andrews P, Aiash H, Habashi NM, Gatto LA. Personalizing mechanical ventilation according to physiologic parameters to stabilize alveoli and minimize ventilator induced lung injury (VILI). Intensive Care Med Exp 2017;5(1):8.

35. Guérin C. Prone position. Curr Opin Crit Care 2014;20(1):92-97.

36. Thompson SG, Higgins J. How should meta-regression analyses be undertaken and interpreted? Stat Med 2002;21(11):1559-1573. 